\title{
METAMORPHISM OF MEGUMA GROUP METASEDIMENTARY ROCKS, WHITEHEAD HARBOUR AREA, GUYSBOROUGH COUNTY, NOVA SCOTIA
}

\author{
Robert $P$. Raeside \\ Department of Geology, Acadia University \\ Wolfville, Nova Scotia BOP $1 \times 0$ \\ John D. Hill \\ Geological Survey of Canada, 601 Booth Street \\ Ottawa, Ontario KIA OE8 \\ present address: \\ Department of Mining Engineering \\ Technical University of Nova Scotia \\ P.O. Box 1000, Halifax, Nova Scotia \\ B3J $2 \times 4$ \\ and \\ Brian G. Eddy \\ Department of Geology, Acadia University \\ Wolfville, Nova Scotia BOP 180 \\ Date Received October 23, 1987 \\ Date Accepted February 9, 1988
}

\begin{abstract}
The metamorphic development of the Whitehead Harbour area is characterized by low pressure, amphibolite facies conditions. Metamorphic grade generally increases toward the margins of early Late Devonian granite plutons. In pelitic 11thologies of the Goldenville and Hallfax Formations, chlorite or chlorite-biotite assemblages \pm albite occur at the lowest grades, chlorite and cordierite overlap in a narrow range, and extensive development of andalusite + biotite occurred at the expense of muscovite + cordierite. Within $300 \mathrm{~m}$ of the contact of granite plutons in areas where post-granite deformation is weak or absent, hornfelsic textures are developed and fibrolite is present. Garnetbiotite geothermometry gields temperatures in the range $317^{\circ} \mathrm{C}$ (chlorite-biotite-albite assemblage) to $665^{\circ} \mathrm{C}$ (sillimanite hornfe1s). Large amounts of spessartine in garnet do not appear to have a significant effect on the calibration of the geothermometer. Application of garnet-plagloclase geobarometers 1s $11 \mathrm{mited}$ because of restricted mineral assemblages, but indicates a maximum pressure of metamorphism of about $350 \mathrm{MPa}$, which is consistent with the aluminosilicate phase diagram.
\end{abstract}

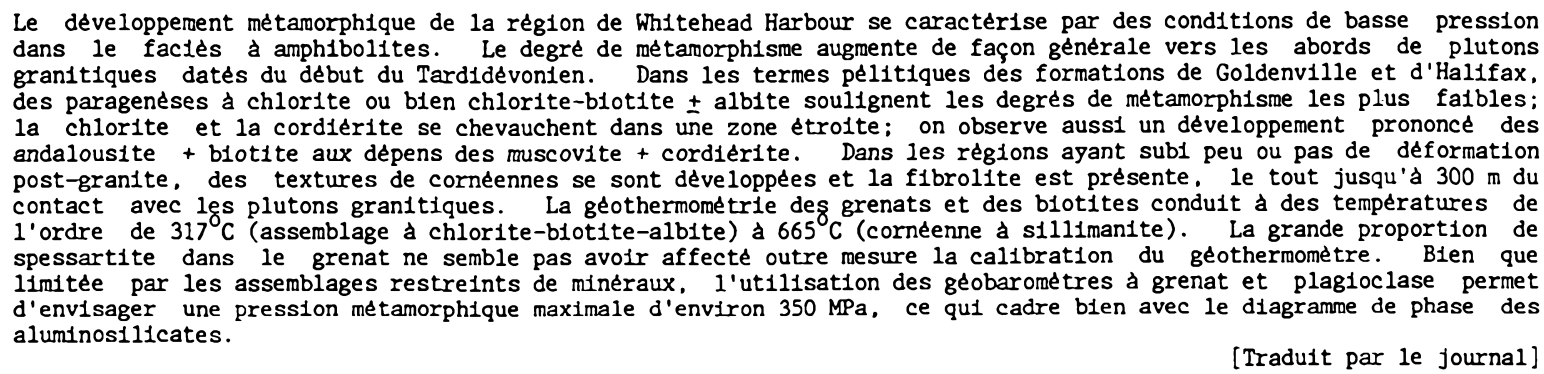

\section{INTRODUCTION}

Recent detailed mapping, petrological and structural studies of the Meguma Terrane in eastern Guysborough County, Nova Scotia, have demonstrated a complex, tightly time-constrained deformation history during the Acadian Orogeny, involving intrusion of granitic plutons and events associated with dextral shearing on the Cobequid-Chedabucto Fault System. The main phases of metamorphism are known to be have occurred at approximately the same time as the deformational events, but the precise timing and the extent of metamorphism have not previously been investigated in detail.

Eastern Guysborough County has been mapped most recently by Hill (1986a, in press) and aspects of the geology of the area have been described by $\mathrm{Hill}$ (1986b, 1987a, 1987b, and this volume), who inferred a three-stage deformational history involving metasedimentary rocks of the Meguma Group and Devonian granitold plutons. D1 fine-scale structures have largely been obliterated by later events in the Whitehead Harbour area, but are we11 displayed in central Guysborough County where they are associated with large-scale folding and upper greenschist facies metamorphism. A second tectonic event (D2) involved complex polyphase deformation associated with dextral transcurrent movements along the Cobequid-Chedabucto Fault System (e.g. , Mawer and White, 1987). The emplacement of the 
plutons occurred after an initial phase of regional deformation (D2a) and was at least partly synchronous with intense, but localized dextral shearing (D2b). Metamorphic mineral growth occurred during D2 (S2 fabric), reaching a peak during D2b, overlapping the emplacement of granitic plutons and static metamorphism. Keppie (1983) proposed that granite plutonism (and therefore associated contact metamorphism) and widespread static metamorphism in the eastern Meguma Terrane were caused by the same thermal event.

\section{GEOLOGY OF THE WHITEHEAD HARBOUR AREA}

The Whitehead Harbour area is underlain by metasedimentary rocks of the Meguma Group (Fig. 1), which have been subdivided into the Goldenville and Halifax Formations by Hill (in press). The Halifax Formation has been further subdivided by $\mathrm{Hill}$ (in press) into five units which appear to have regional extent in eastern Guysborough County. These units include black graphitic schist, coticule-bearing quartz-muscovite schist, metagreywacke, coticule-bearing andalusite schist, and coticule-free phyllite. Rocks assigned to the Goldenville Formation include fine-grained laminated meta-greywacke intercalated with relatively massive meta-greywacke and minor metapelite, rare meta-arenite and calc-silicate lenses (Hill, 1986b, in press). Near the top of the Goldenvilie Formation, beds are thinner and the proportion of metapelite is greater, as is observed in other areas of the Meguma Group (McBride, 1978; O'Brien, 1985; Waldron and Graves, 1987).

The effects of regional D1 deformation and upper greenschist facies metamorphism are rarely preserved and in most areas D1 fabrics have been overprinted and transposed into upper greenschist facies $\mathrm{D} 2 \mathrm{a}$ and amphibolite facies $\mathrm{D} 2 \mathrm{~b}$ fabrics (Hil1, 1987b). To the east of the Whitehead Harbour area a number of small tonalite plutons dated at $378 \pm 2 \mathrm{Ma}$ (Krogh, cited in Hill, this volume) post-date the D1 fabric development, but display a D2 fabric, and therefore provide an older limit for D2 deformation. Both the Halifax and Goldenville Formations have been intruded by early Late Devonian ( $372 \pm 1 \mathrm{Ma}, \mathrm{U}-\mathrm{Pb}$, monazite age) muscovite-biotite granite plutons following D2a fabric development, but at least partly penecontemporaneous1y with $\mathrm{D} 2 \mathrm{~b}$ and the main phase of metamorphism. In the Whitehead Harbour area most mineral growth is due to the presence of the Flagstaff Hill, Whitehead, Prices Island and Port Howe Plutons (Hi11, in press), around which a metamorphic aureole has been mapped. Ductile deformation ceased before deposition of the overlying undeformed Horton Group sedimentary rocks (Tournaisian). The main phase of D2 deformation, granite plutonism and metamorphism is therefore limited to a 10 to $30 \mathrm{Ma}$ period.

of particular importance to the analysis of the metamorphic conditions displayed by the rocks of the Whitehead Harbour area is the abundance of highly aluminous lithologies in the Halifax Formation, some of which contain extensively developed andalusite, sillimanite, cordierite, biotite, and garnet. These minerals permit determination of the grade of metamorphism and have the potential for allowing geothermometric and geobarometric estimates of the metamorphic conditions based on ion exchange equilibria between grains in equilibrium.

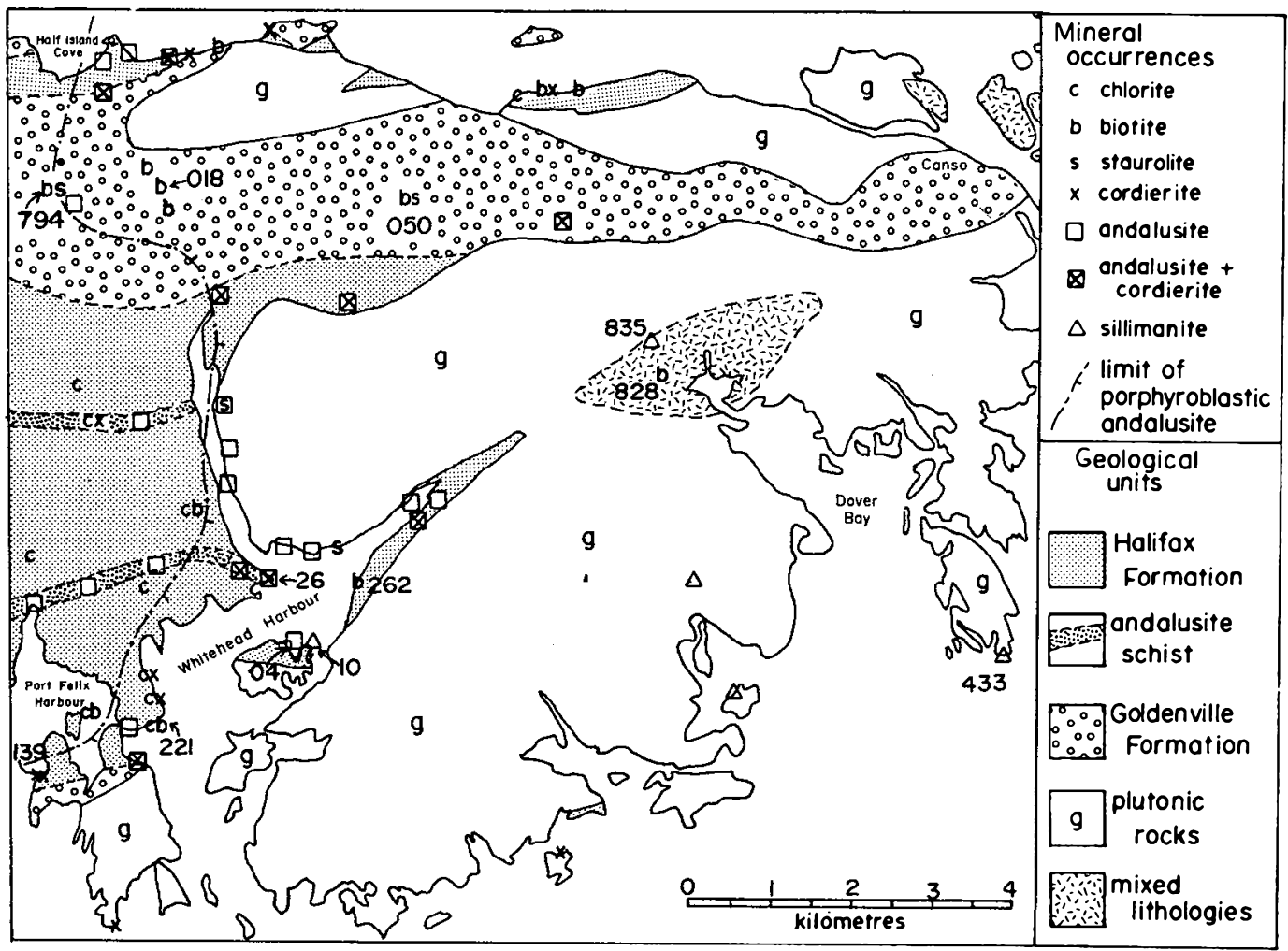

Fig. 1. Geological map of eastern Guysborough County, showing the distribution of significant metamorphic mineral occurrences. Garnet occurs in all the samples identified. 


\section{MINERAL ASSEMBLAGES}

Figure 1 shows the geographic distribution of significant minerals in pelitic and semipelitic rocks in the Whitehead Harbour area. In general, metamorphic grade appears to be a function of the distance from the contact of a granitic pluton. Mineral assemblages from four metamorphic zones are summarized on Figure 2.

Garnet is found in samples from all grades of metamorphism. In most rocks it occurs as fine grained, idioblastic crystals, which have cores crowded with inclusions of quartz and opaque minerals, and rims free of inclusions. There is no obvious metamorphic unconformity between these cores and rims, although the garnets are commonly chemically zoned (Fig. 3). In some rocks, garnet aggregates mantle pyrite grains and lack the inclusion-rich cores. A third mode of occurrence of garnet is in coticule layers. These are composed of garnet and quartz \pm plagloclase, with garnet comprising $25-95 \%$ of the layer. Coticule layers are prominent in outcrop, being up to $15 \mathrm{~cm}$ thick, and continuous across outcrops. Typically they have behaved more competently than the surrounding rock during deformation, but are nonetheless extensively folded. The composition of the garnet is variable, commonly rich in manganese, with spessartine contents typically 20-40\%, but ranging from 8-53\%. Grossular contents are less than $10 \%$ in almost all samples, and the $\mathrm{Mg}: \mathrm{Fe}$ ratio ranges from 0.048 to 0.161 . Garnets in coticule layers are not noticeably more enriched in spessartine than those from other lithologles.

Evidence of limited retrograde metamorphism is common in all lithologies. Typically it is limited to the growth of chlorite knots in micaceous rocks, although sericitization of andalusite and pinitization of cordierite has occurred in some areas. In thin section, limited wrapping of the fabric around chlorite knots can be observed, indicating continued recrystallization of matrix minerals after the main phase of metamorphism.

\section{Chlorite Zone}

The lowest grade rocks in the area are chloritegarnet and biotite-chlorite-garnet phyllites (Fig. 2a), which typically occur at distances greater than $1 \mathrm{~km}$ from the mapped contacts of granite plutons. Albite $\left(\mathrm{An}_{1-3}\right)$ or plagioclase $\left(\mathrm{An}_{15-37}\right)$ occurs in approximate $1 \bar{y}$ half the samples. Afbitebearing rocks are restricted to those areas most distant from the plutons. In the Northwest Arm of Whitehead Harbour, the diagnostic assemblage chlorite-blotite occurs close to the pluton; the matrix of these phyllites is composed of finegrained white mica, chlorite, quartz, garnet, and opaque minerals (mainly magnetite and graphite), although some samples also contain albite. Biotite rarely occurs as a groundmass phase in these phyllites, but is widespread as small porphyroblasts resulting in an obvious spotted appearance in thin section and hand specimen. Although biotite probably forms from reaction between muscovite and chlorite, no replacement textures to confirm such a reaction were observed. Biotite appears to be more abundant in the low grade meta-greywackes of the Goldenville Formation in the northern part of the area. In the more

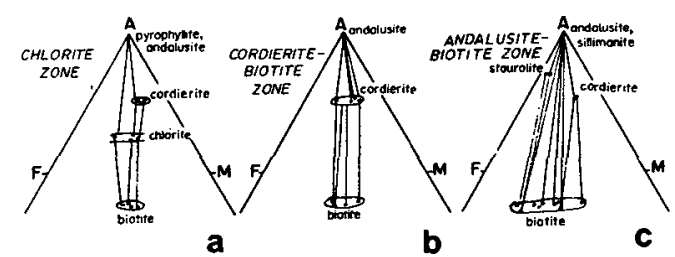

Fig. 2. AFM projections of the AFMK tetrahedron showing the mineral assemblages developed in the Whitehead Harbour area.

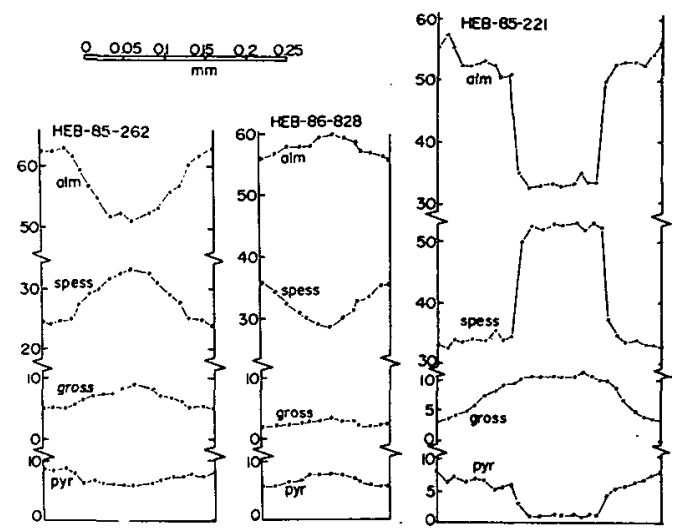

Fig. 3. Zoning profiles of typical garnet grains from three samples, illustrating the range of garnet zoning encountered. Profiles were constructed for one of the largest garnet grains in each thin section, and extend from rim to rim.

aluminous rocks of the Halifax Formation, which are more extensive in the south, the assemblages chlorite-muscovite-albite-cordierite and chloritemuscovite-andalusite, both without biotite, are wide1y developed (Eddy, 1987; Fig. 2a).

Andalusite and cordierite are restricted to the most aluminous 1ithologies in the chlorite zone (Fig. 2a). The main development of andalusite and cordierite is outside the chlorite zone and to the east of a line from Half Island Cove to Port Felix Harbour (Fig. 1). Up to $2 \mathrm{~km}$ west of this line, in unit $D$ of the Halifax Formation ( $H 111$, in press) however, andalusite occurs as porphyroblasts in a coticule-bearing schist horizon (F1g. 1). The low grade andalusite metacrysts are typically banded, with cloudy layers containing abundant inclusions of submicroscopic opaque minerals corresponding to quartzofeldspathic layers in the matrix, and clear layers which can be traced into muscovite-rich bands in the matrix. This texture indicates andalusite grew at the expense of the micaceous layer, which is inferred to have been pyrophylliterich during the early stages of metamorphism (corresponding to D1). The inclusions in the andalusite are much finer grained than the present groundmass of the rock, suggesting the andalusite may have originally overgrown a matrix which was finer grained than that now preserved outside the porphyroblasts, and also finer grained than any other low grade phyllitic lithologies identified in the area. The andalusite may have developed in this very aluminous 11thology by the reaction (Miyashiro, 1973):

pyrophyllite = andalusite + quartz,

which takes place at much lower temperatures than the biotite or cordierite-producing reactions. 


\section{Cordierite-Biotite Zone}

In all 11thologies which contain cordierite except unit $D$ of the Halifax Formation, described above, the cordierite appears to have developed at lower grade conditions than andalusite. Cordierite is typical of quartzofeldspathic 1ithologies, especially those with abundant feldspar and garnet. A possible reaction for the formation of cordierite that 1s appropriate to the rocks of the study area has been proposed by Pattison and Harte (1985): muscovite + chlorite +2 quartz cordierite + biotite + water.

However, at least one sample from the western part of the area lacks biotite, indicating that either potassium was removed by the amblent metamorphic fluids, or that muscovite was not directly involved in the initial cordierite-producing reaction in that rock. Cordlerite remains as a stable phase to the highest metamorphic grades displayed by the rocks of the Whitehead Harbour area, typically in association with biotite (F1gs. 2b, c). Therefore, the reaction described above probably represents the upper grade limit of chlorite.

\section{Andalusite-Biotite Zone}

Like cordierite, andalusite occurs as both porphyroblast and groundmass phases. In samples which contain both cordierite and andalusite, the andalusite has overgrown cordlerite, or has overgrown a fabric which is wrapped around cordierite. The cordierite is typically very ragged and embayed, whereas the andalusite is 1dioblastic. The cordierite is inferred to be unstable, and decomposing by the reaction (Pattison and Harte, 1985):

$$
2 \text { muscovite }+3 \text { cordierite - }
$$

7 quartz +8 andalusite +2 biotite +3 water. As a result of this reaction, the assemblage andalusite-biotite is stable and andalusite can form over a much wider range of bulk compositions in AFM space and is no longer restricted to highly aluminous 11thologies (Fig. 2c). All samples examined containing cordierite and andalusite also contain porphyroblasts of biotite, which are otherwise restricted in the aluminous rocks of the Whitehead Harbour area. Staurolite is also rare in the area, having been recorded in four localities (Fig. 1). Its restricted distribution appears to be a result of the limited distribution of high $\mathrm{Fe} / \mathrm{Fe}+\mathrm{Mg}$ 11thologies (Fig. 2c).

\section{Sillimantte Zone}

Within $300 \mathrm{~m}$ of the mapped contacts of the granites, the metasedimentary rocks are strongly hornfelsed, although at many contacts subsequent localized deformation has resulted in the development of a later schistose fabric. In some xenoliths and in hornfelses not affected by later deformation, relict bedding and an early tectonic follation are commonly preserved, but fine scale features of the follation development have been largely obliterated by recrystallization of muscovite, andalusite, plagioclase and quartz. Sillimanite (fibrolite in all samples except 86-BE10) Is commonly developed adjacent to the contacts. but most sillimanite-bearing samples also contain andalusite. Andalusite in the hornfelses can be distinguished from porphyroblastic andalusite elsewhere. Typically the hornfelses are equigranular and the andalusites are 1-3 mm across, xenoblastic and contain few inclusions. In many cases, the cores of the andalusite grains are strong1y pleochroic pink, and contain up to $2.6 \mathrm{wt} \%$ $\mathrm{Fe}_{2} \mathrm{O}_{3}$ ( 6 mol\% viridine). In spite of the high $\mathrm{Mn}$ content of many of the rocks, the andalusites are not enriched in kanonaite--Mn was not detected in any of the analyzed pleochroic andalusite cores (Eddy, 1987).

\section{PHYSICAL CONDITIONS OF METAMORPHISM}

The determination of the temperature and pressure conditions of metamorphism in the Whitehead Harbour area is complicated by the possibility of multiple episodes of re-equilibration of assemblages, and by the unusual mineral compositions in some of the 1ithologies. H111 (1987a, 1987b) has postulated that the peak of metamorphism occurred during D2 throughout much of the area, specifically during a phase of static metamorphism that was approximately coeval with intrusion of granite plutons. Effects of earlier metamorphic episodes are generally obliterated, but may be preserved west of the Whitehead Harbour area where upper greenschist facies metamorphism is associated with the large scale (D1) folding of the Meguma Group (Keppie, 1983). Later metamorphic episodes are generally considered to be retrograde on D2.

Analytical Techniques

Thirteen samples which contain stable biotite and garnet were selected for geothermometry. Mineral analyses were made at the Dalhousie Regional Electron Microprobe Laboratory, Halifax, using a JEOL 733 Superprobe. A combined wavelength and energy dispersive analytical technique was used, involving up to four simultaneous analyses and automated spectrometer drive to collect analyses of ten major elements. An accelerating voltage of 15 $\mathrm{kV}$, a probe current of about $5{ }_{6} \times 10^{-9}$ amp, and a beam dlameter of about $1 \times 10^{-6} \mathrm{~m}$ were used. At least three analyses were made on each grain or portion of grain. Zoned minerals (garnets) were traversed with successive analyses across the largest grains in each polished thin section separated by about $0.01 \mathrm{~mm}$. Data reduction of raw counts to corrected weight percent of oxides was done using Traycor Northern ZAF software.

\section{Garnet Zoning}

In most of the rocks selected for garnet-biotite geothermometry the garnets are zoned, generally with higher $\mathrm{Mn}$ contents and $\mathrm{Mg} / \mathrm{Fe}$ ratios in the cores. Some garnets show Mn enrichment in their rims, however, which cannot be considered to be due entirely to retrograde processes, as these garnets are texturally identical to garnets with Mn-rich cores. Zoning profiles are 1llustrated in Figure 3. The garnet in HEB-85-262 is typical of most samples, and displays continuous growth zoning with a we11-defined core enriched in $\mathrm{Ca}$, a gradual drop of $\mathrm{Mn}$ from core to $\mathrm{rIm}$, and an increase in both $\mathrm{Mg}$ and $\mathrm{Fe}$ from core to rim. Garnet in HEB-86-828 is from a coticule layer, and 1llustrates the "reverse" zoning profile with an enrichment of $\mathrm{Mn}$. 
and depletion of $\mathrm{Ca}, \mathrm{Mg}$ and $\mathrm{Fe}$ in the rim. The origin of this type of zoning profile is unknown in the rocks of the Whitehead Harbour area--1t appears to be restricted to the coticule-bearing layers, and may reflect growth of garnet at the expense of a Mn-bearing chlorite or 1lmenite. The garnet in HEB-85-221 shows a metamorphic unconformity (Tracy. 1982) with a distinct core, enriched in $\mathrm{Mn}$ and $\mathrm{Ca}$, and a "normal" zoning profile in the outer part, with gradual depletion of $\mathrm{Ca}$ and $\mathrm{Mn}$, and enrichment of both $\mathrm{Mg}$ and $\mathrm{Fe}$. The step in end member concentrations between the core and mantle is interpreted to have been caused by garnet growth from different reactants, and possibly different metamorphic events. Mineral assemblage and compositional data for garnet and biotite in thirteen samples are summarized on Tables 1 and 2 .

\section{Garnet-B1otite Geothermometry}

Temperatures of equilibration have been calculated for core and rim garnet compositions in a11 assemblages, although in no case is there evidence to conclude the garnet cores were in equilibrium with the present biotite composition. Biotite compositions are uniform across the scale of an individual thin section, and the present biotite composition is assumed to be in equilibrium with the outer zones of the garnets. No significant difference in $\mathrm{Mg}: \mathrm{Fe}$ ratio was detected in biotites adjacent to or far from garnets. The determination of "garnet rim" analyses involved averaging the composition of the outer 25\% (radius) of at least three garnet grains in each rock, and in a11 cases where standard deviations of these averages were determined, all analyses fell within two standard deviations of the mean, indicating that garnet rims were in equilibrium with each other, and 1mplying they were simultaneously undergoing ionic exchange with biotite. Garnet core analyses, from three of the largest garnets in each thin section, were highly varlable, although it is not known if this is a function of large differences in the core compositions or because some "cores" were not cut through the true centres of grains.

Four calibrations were employed in the determination of temperature (Table 2). T1 and T2 (Ferry and Spear, 1978; Thompson, 1976 calibrations, respective1y) are based on the $\mathrm{Mg}-\mathrm{Fe}$ partitioning between garnet and biotite and do not specifically take into account the presence of $\mathrm{Mn}$ or $\mathrm{Ca}$ in garnet. They must therefore be considered suspect in these rocks which have very high spessartine garnets. T3 (P1gage and Greenwood, 1982) is based on the Ferry and Spear (1978) calibration, with empirically derived corrections for $\mathrm{Ca}$ and $\mathrm{Mn}$ in garnet. T4 (Hodges and Spear. 1982) is also based on the Ferry and Spear (1978) calibration, but includes the calculated effects of non-1deal mixing of $\mathrm{Ca}$ in garnet. Hodges and Spear (1982) noted that $\mathrm{Mn}$ appears to $\mathrm{mix}$ 1deally with $\mathrm{Fe}$ and $\mathrm{Mg}$ in the garnet structure, and therefore should have no effect on the calibration of the geothermometer, behaving only as a dilutant in the solid solution. The possibility of non-zero interaction parameters between $\mathrm{Mn}$ and $\mathrm{Ca}$ is of less importance in these garnets which contain very small amounts of the grossular component.

\section{Results}

In Table 2 the samples have been subdivided into four groups, on the basis of mineral assemblages: (1) chlorite + albite, (11) chlorite + calcic plagloclase $\left(\mathrm{An}_{15-37}\right)$, (111) cordierite-biotite or andalusite-biotite (no chlorite), and (iv) sillimanite. In addition, one sample (HEB-85-050) which lacks chlorite, andalusite, cordierite and sillimanite is compatible with either of the latter

Table 1. Mineral assemblages of samples used for geothermometry and geobarometry. Abbreviations on table: P - porphyroblasts, $\mathbf{X}$ - present, f - fibrolite, g - graphite, 1 - 11menite, $m$ - magnetite, $m i$ - microcline, 0 orthoclase, p - pyrite, numbers under plagioclase - mo1\% anorthite.

Sample

HEB-85-018

HEB-85-050

HEB-85-139

HEB-85-221A

HEB-85-262

HEB-85-433C

HEB-86-792B

HEB-86-794

HEB-86-828

HEB-86-835

$86-\mathrm{BE}-04$

$86-\mathrm{BE}-10$

$86-\mathrm{BE}-26$

qz quartz

p1 plagioclase

Kf K-feldspar

mu muscovite qz p1 Kf mu b1 ch an si st gt co to zr ap op

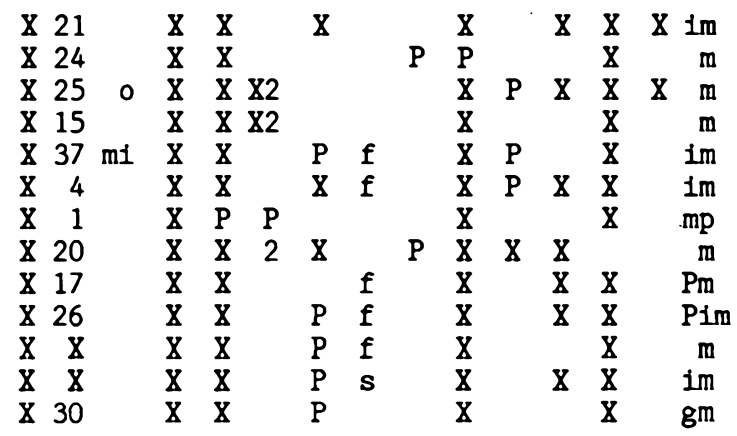

bi biotite

ch chlorite

an andalusite

st staurolite

gt garnet

co cordierite

si sillimanite to tourmaline zr zircon

ap apatite

op opaque

minerals 
Table 2. Summary of compositional data for garnet and biotite, and temperatures derived from four geothermometric calibrations: T1, Ferry and Spear (1978); T2, Thompson (1976); T3, P1gage and Greenwood (1982); T4, Hodges and Spear (1982). Letters after sample number indicate the site of the garnet analysis: $c$, core; $r$, rim; inter, interior; anda1, both garnet and biotite enclosed within andalusite porphyroblasts. All samples are prefixed by HEB-85, HEB-86 or 86-BE (see Table 1).

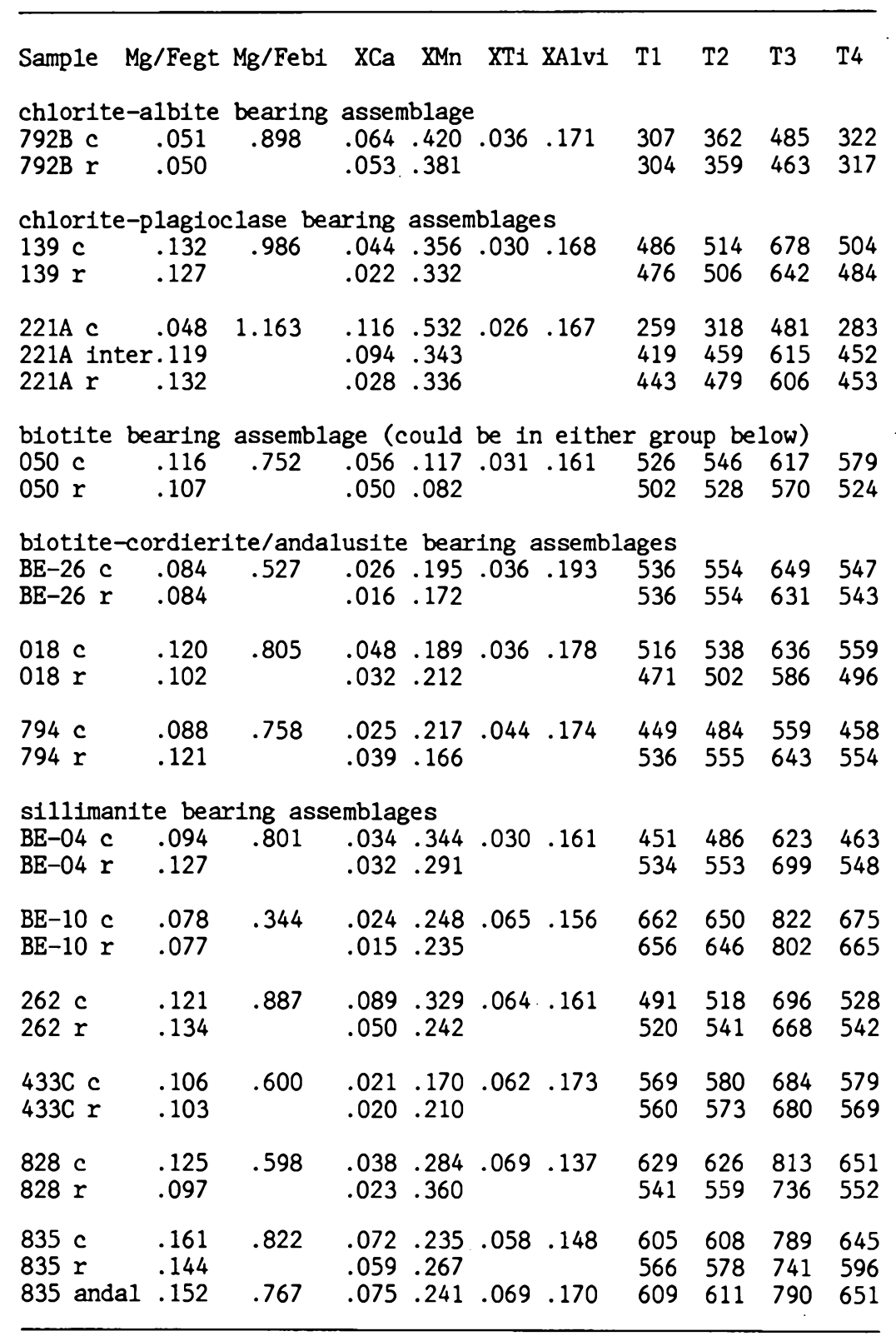

two higher grade zones. It has been assigned to the cordierite/andalusite + biotite group based on its geographic position. The temperatures derived from garnet rim-biotite analyses using the four calibrations of the geothermometer vary by up to $195^{\circ} \mathrm{C}$. However, a degree of internal consistency with any single calibration is apparent when the results are compared with the four groups noted above. The calibration of Pigage and Greenwood
(1982) yields consistently higher temperatures than other calibrations. The calibration of Hodges and Spear (1982) yields the set of temperatures which are most consistent within each of the four groups, with samples from each higher grade zone yielding increasing $1 \mathrm{y}$ higher temperatures $\left( \pm 10^{\circ} \mathrm{C}\right)$. Temperatures range from $317^{\circ} \mathrm{C}$ in the chlorite-albite assemblage to $665^{\circ} \mathrm{C}$ from sillimanite-bearing hornfels in the contact zone of a granite pluton. 


\section{Pressure Determinaticn}

Pressure of metamorphism can be determined in pelitic rocks from the exchange of $\mathrm{Ca}$ between garnet and plagioclase in those rocks saturated in $\mathrm{A} 1$ and $\mathrm{Si}$. In the samples from the Whitehead Harbour area, andalusite or sillimanite (to satisfy aluminum saturation requirements) is present in nine samples. Of these, plagioclase was analyzed in seven, but in $\mathrm{HEB}-85-433 \mathrm{C}$ it contains $4 \mathrm{mo} \%$ anorthite, outside the range of calibration of the geobarometers. Pressures have been determined from the remaining six samples using temperatures determined from the Hodges and Spear (1982) geothermometer and the calibrations of Ghent et al. (1979) and Newton and Hase1ton (1981), modified by St. Onge (1984) for andalusite-bearing samples (Table 3). The accuracy of this geobarometer is about $\pm 150 \mathrm{MPa}$ (Ghent et al., 1979), and is largely dependent on the garnet mixing model employed and on the input temperature data.

The pressures derived using this geobarometer (Newton and Haselton calibration) range from 53 to $661 \mathrm{MPa}$, although the presence of scattered knots of fibrolite in three of the samples indicates that andalusite was not in equilibrium with the plagioclase and garnet in later stages of recrystallization of these rocks, and the values determined using the andalusite polymorph can be ignored. The pressures calculated using the Newton and Haselton (1981) calibration in sillimanitebearing rocks range from 338 to $375 \mathrm{MPa}$. The wide spread of pressures calculated from the Ghent et al. (1979) calibration is greater than the error in the technique, but may be affected by the unknown effects of mixing of $\mathrm{Ca}-\mathrm{Mn}$ in high spessartine garnets.

The pressure of metamorphism has been determined qualitatively by examining the phase relationships of the minerals on a petrogenetic grid. Figure 4 shows the distribution of assemblages in $\mathrm{P}-\mathrm{T}$ space, using the aluminosilicate triple point of Holdaway (1971) modified for fibrolite after Kerrick (1987). Rocks which contain both andalusite and fibrolite or sillimanite can be plotted directly, using the temperatures derived from garnet-biotite geothermometry. The presence of fibrolite in place of sillimanite in several samples may indicate pressures derived from andalusite-fibrolite-bearing rocks plot up to $30 \mathrm{MPa}$ lower than the andalusitesillimanite phase boundary (Kerrick, 1987). The resulting pressures are generally in good agreement with the Newton and Hase1ton (1981) calibration of the geobarometer (except for sample 86-BE-26), and place an approximate upper limit of $350 \mathrm{MPa}$ on the peak metamorphic conditions of the main phase of metamorphism, associated with the intrusion of the granite plutons. This value is consistent with the presence of magmatic manganiferous garnet $(26 \%$ spessartine) in one pluton which suggests crystallization at pressures of at least $300 \mathrm{MPa}$ (Green, 1977) and by the inferred presence of magmatic cordierite (now replaced by smectite aggregates) indicating crystallization at pressures less than $500 \mathrm{MPa}$ (Clemens and Wa11, 1981).

\section{DISCUSSION AND CONCLUSIONS}

Although microfabric studies of the Meguma Group lithologies of the Whitehead Harbour area indicate a sequential deformational history, including the intrusion of a number of granite plutons, the main metamorphic development appears to be associated with the D2b phase, and is constrained to a 10-30 $\mathrm{Ma}$ period of deformational history by radiometric dating of pre-D2 tonalitic plutons and the depositional age (Tournaisian) of the overlying Horton Group sedimentary rocks. This interval includes the intrusion of the plutons, and the main phase of metamorphism (Hill, in press, and this volume).

The lowest grade rocks of the area display chlorite-albite assemblages, some with biotite. indicating middle greenschist facies conditions. Garnet-biotite geothermometry of one sample from these rocks yields a very low temperature of $317^{\circ} \mathrm{C}$. Grade increases rapidly toward the east and in the vicinity of granite plutons, with the appearance of oligoclase-andesine plagioclase and cordierite. Transitional greenschist-amphibolite facies assemblages including chlorite and plagioclase yield temperatures of $450-480^{\circ} \mathrm{C}$. Andalusite or

Table 3. Summary of compositional data for garnet and plagioclase, and pressures derived from two geobarometric calibrations: P1, Ghent et al. (1979); P2, Newton and Haselton (1981), modified by St. Onge (1984) for andalusite-bearing assemblages.

\begin{tabular}{|c|c|c|c|c|c|c|c|c|c|c|c|c|c|}
\hline Sample & $\begin{array}{l}\mathrm{Al}_{2} \mathrm{SiO}_{5} \\
\text { polymorph }\end{array}$ & $\mathrm{T}^{\circ} \mathrm{K}$ & $x_{g r}^{g t}$ & $x_{p y}^{g t}$ & $x_{a 1 m}^{g t}$ & $x_{s p}^{g t}$ & $\mathrm{x}_{\text {an }}^{\mathrm{p} 1}$ & $a_{\text {an }}^{p 1}$ & $a_{g r}^{g t}$ & $\log \mathrm{Ks}$ & $-\Delta G_{A}^{0}$ & $\Delta \overline{\mathrm{V}}$ & P1 \\
\hline $\mathrm{HEB}-85-018$ & anda1 & 769 & .032 & .070 & .687 & .212 & .210 & .397 & .035 & -3.164 & 14587 & 1.225 & 380 \\
\hline$E B-86-794$ & anda1 & 827 & .039 & .086 & .709 & .166 & .195 & .322 & .043 & -2.623 & 16578 & 1.227 & 597 \\
\hline $6-B E-26$ & anda1 & 816 & .016 & .063 & .749 & .172 & .295 & .542 & .017 & -4.511 & 16200 & 1.215 & 62 \\
\hline $\begin{array}{l}E B-85-262 \\
E B-85-262\end{array}$ & $\begin{array}{l}\text { andal } \\
\text { sill }\end{array}$ & $\begin{array}{l}815 \\
815\end{array}$ & $\begin{array}{l}.050 \\
.050\end{array}$ & $\begin{array}{l}.084 \\
.084\end{array}$ & $\begin{array}{l}.625 \\
.625\end{array}$ & $\begin{array}{l}.242 \\
.242\end{array}$ & $\begin{array}{l}.372 \\
.372\end{array}$ & $\begin{array}{l}.675 \\
.675\end{array}$ & $\begin{array}{l}.055 \\
.055\end{array}$ & $\begin{array}{l}-3.267 \\
-3.267\end{array}$ & $\begin{array}{l}16166 \\
16608\end{array}$ & $\begin{array}{l}1.230 \\
1.230\end{array}$ & $\begin{array}{l}416 \\
294\end{array}$ \\
\hline $\begin{array}{l}\mathrm{HEB}-86-835 \\
\mathrm{HEB}-86-835\end{array}$ & $\begin{array}{l}\text { anda1 } \\
\text { sill }\end{array}$ & $\begin{array}{l}869 \\
869\end{array}$ & $\begin{array}{l}.059 \\
.059\end{array}$ & $\begin{array}{l}.085 \\
.085\end{array}$ & $\begin{array}{l}.589 \\
.589\end{array}$ & $\begin{array}{l}.267 \\
.267\end{array}$ & $\begin{array}{l}.264 \\
.264\end{array}$ & $\begin{array}{l}.437 \\
.437\end{array}$ & $\begin{array}{l}.065 \\
.065\end{array}$ & $\begin{array}{l}-2 \\
-2\end{array}$ & $\begin{array}{l}18020 \\
14045\end{array}$ & $\begin{array}{l}1.232 \\
1.232\end{array}$ & $\begin{array}{l}728 \\
576\end{array}$ \\
\hline$E B-86-828$ & sill & 825 & .023 & .054 & .563 & .360 & .169 & .267 & .025 & -3.086 & 16211 & 1.218 & 314 \\
\hline
\end{tabular}




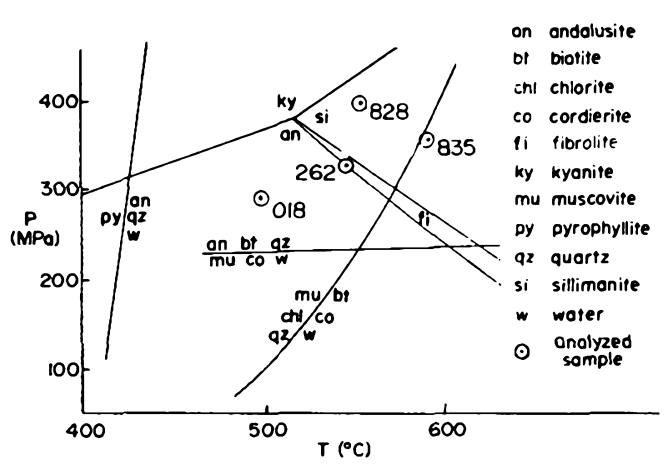

Fig. 4. Pressure-temperature plot showing the distribution of assemblages and reactions identified in the Whitehead Harbour area. Aluminosilicate triple point from Holdaway (1971), fibrolite stability field after Kerrick (1987), pyrophyllite breakdown reaction from Miyashiro (1973), cordierite reactions from Pattison and Harte (1985).

cordierite-bearing assemblages, lacking prograde chlorite are widespread, and yield temperatures of $500-550 \mathrm{C}$. These appear to represent the peak conditions of regional static metamorphism, which overlapped D2b. The intrusion of granite plutons locally elevated metamorphic temperatures to over $600^{\circ} \mathrm{C}$, allowing the development of fibrolite and sililmanite. Although the relationship between static metamorphism (i.e.. regionally elevated temperatures) and contact metamorphism (hornfelsing restricted to $300 \mathrm{~m}$ from the contact of a pluton) is uncertain, the data are compatible with Keppie's (1983) model that both were caused by the same thermal event.

Garnet in the pelitic schists and coticules is typical of garnet throughout the Meguma Group, having high spessartine and low grossular contents. As a result of the high spessartine content, garnet is developed in suitable 1ithologies in chloritebearing rocks. At higher grades it is generally less enriched in spessartine, suggesting that $\mathrm{Mn}$ has exchanged with other phases in the rock, possibly 11menite, the most abundant oxide phase. Preliminary microprobe analyses of 1lmenites indicate up to $4 \mathrm{wt} \% \mathrm{MnO}$. The $\mathrm{Fe}-\mathrm{Mg}$ exchange between garnet and biotite appears to be unaffected by the high spessartine contents, and the calibration of the geothermometer by Hodges and Spear (1982) yields the most consistent set of temperatures, which are in agreement with Holdaway's (1971) calibration of the andalusitesilimanite reaction in andalusite-sillimanitegarnet-biotite 1ithologies.

Anomalous distribution of some minerals appears to be the result of local restricted compositions. Andalusite which formed in particularly aluminous layers, up to $2 \mathrm{~km}$ west of its regional development, probably developed from the decomposition of pyrophyllite in these layers, rather than by reaction between muscovite and cordierite as is $11 k e 1 y$ elsewhere. This reaction occurs at about $400^{\circ} \mathrm{C}$ (Miyashiro, 1973), and the andalusite may have developed before the main phase of metamorphism, during the regional D1 chlorite grade metamorphism (Hi11, in press).

The metamorphic rocks of the Whitehead Harbour area appear to represent the highest grades of metamorphism exhibited in the Meguma Terrane of eastern Nova Scotia. Metamorphic temperatures were locally elevated in the contact zones of granitic plutons, resulting in the development of sillimanite, but the regional metamorphic culmination achieved temperatures of about $550^{\circ} \mathrm{C}$, allowing the development of cordierite-andalusite assemblages. Pressures determined from garnetplagioclase geobarometry, from the analysis of phase relationships, and from petrological study of the plutons are consistent with each other, at about $350 \mathrm{MPa}$, indicating a depth of metamorphism and intrusion of about 10 to $11 \mathrm{~km}$. The close time constraints on metamorphism, granite intrusion, and deformation (all overlapping the D2b event) imply a regionally elevated heat flow in this part of the Meguma Terrane, which diminished to the west into areas where the peak metamorphic conditions reached lower to middle greenschist facies. Similar high heat flow conditions with spatially and temporally associated plutonism have been noted in other areas of the Meguma Terrane, e.g., in the vicinity of the Port Mouton Pluton (Hope et al., in press) and in southwestern Nova Scotia (Raeside et al., 1985), and appear to be characteristic of the evolution of the terrane.

\section{ACKNOWLEDGEMENTS}

We thank Dan Kontak for organizing this issue on Meguma Terrane geology, and Becky Jamieson for discussions on the petrology. The manuscript benefitted considerably from the constructive reviews of Victor Owen and Toby Rivers. Samples were collected during fleld research funded by the Geological Survey of Canada (to JDH) and petrological studies were funded by an NSERC operating grant to RPR. We are grateful for the assistance provided to RPR and BDE by R. Mackay of the Dalhousie Regional Electron Microprobe Laboratory for microprobe studies.

CLEMENS, J.D. , and WALL, V.J. 1981. Origin and crystallization of some peraluminous (S-type) granitic magmas. Canadian Mineralogist, 19. pp. 111-132.

EDDY, B.G. 1987. Deformation and metamorphism of the Whitehead Harbour area, Guysborough County. Nova Scotia. B.Sc. thesis, Acadia University, Wolfville, Nova Scotia, 94 p.

FERRY. J.M. , and SPEAR, F.S. 1978. Experimental calibration of the partitioning of $\mathrm{Fe}$ and $\mathrm{Mg}$ between biotite and garnet. Contributions to Mineralogy and Petrology. 66, pp. 113-117.

GHENT, E.D. . ROBBINS, D.B., and STOUT, M.Z. 1979. Geothermometry, geobarometry, and fluid compositions of metamorphosed calc-silicates and pelites. Mica Creek, British Columbia. American Mineralogist. 64, pp. 874-885.

GREEN, T.H. 1977. Garnet in silicic liquids and its possible use as a P-T indicator. Contributions to Mineralogy and Petrology, 65, pp. 59-67.

HILL, J.D. 1986a. Geological map of Cape Canso, Nova Scotia. Geological Survey of Canada, Open F1le 1276.

HILL, J.D. 1986b. Granitoid plutons in the Canso area, Nova Scotia. Current Research, Part A, Geological Survey of Canada, Paper 86-1A. pp. 185-192.

HILL, J.D. 1987a. Geology of the Guysborough-Country Harbour area, Nova Scotia. Current Research, Part A, Geological Survey of Canada. Paper 87-1A, pp. 415-422.

HILL, J.D. 1987b. Sequence of structural, metamorphic and intrusive events in the Canso and Forest Hill map areas eastern Meguna Terrane, Nova Scotia. In Mines and Minerals Branch, Report of Activities. Edited by J.L. Bates and D.R. MacDonald. Nova Scotia Department of Mines and Energy. Report 87-5, pp. 201-206.

HILL, J.D. In press. Geology of the Canso and Forest H111 areas, eastern Meguma Terrane. Nova Scot1a, with emphasis on the petrology, tectonic setting and economic potential of late Devonian granitold bodies. Geological Survey of Canada Bulletin.

HODGES, K.V., and SPEAR, F.S. 1982. Geothermometry. geobarometry and the $\mathrm{Al}_{2} \mathrm{SiO}_{5}$ triple point at Mt. Moosilauke. New Hampshre. American Mineralog1st, 67, pp. 1118-1134. 
HOLDAWAY, M.J. 1971. Stab1l1ty of andalusite and the aluminum silicate phase diagram. American Journal of Sc1ence, 271, pp. 97-131.

HOPE, T.L., DOUMA, S.L., and RAESIDE, R.P. In press. Geology of the Port Mouton-Lockeport area, southwestern Nova Scot1a. Geological Survey of Canada, Open File Report.

KEPDIE. J.D. 1983. Geological history of the Isaacs Harbour area, parts of $11 F / 3$ and $11 F / 4$. Guysborough County, Nova Scotia. In Mines and Minerals Branch, Report of Activities. Edited by K.A. Mills. Nova Scot1a Department of Mines and Energy, Paper 83-1. pp. 109-143.

KERRICK, D.M. 1987. Fibrolite in contact aureoles of Donegal. Ireland. American Mineralogist, 72, pp. 240-254.

MAIJER, C.K., and WHITE, J.C. 1987. Sense of displacement on the Cobequid-Chedabucto fault system. Nova Scotia, Canada. Canadian Journal of Earth Sc1ences, 24, pp. 217-233.

MCBRIDE, D.E. 1978. Geology of the Ecum Secum area, Hallfax and Guysborough Counties, Nova Scotia. Nova Scotia Department of Mines and Energy. Paper 78-1, $12 \mathrm{p}$.

MIYASHIRO, A. 1973. Metamorphism and Metamorphic Belts. Allen and Unwin, London, $492 \mathrm{p}$.

NEWTON, R.C. , and HASELTON, H.T. 1981. Thermodynamics of the garnet-plagioclase-Al $\mathrm{SiO}_{5}$-quartz geobarometer. In Thermodynamics of Minerals afd Me1ts. Edited by R.C. Newton, A. Navrotsky, and B.J. Wood. Springer-Verlag. New York, pp. 131147 .

O'BRIEN, B.H. 1985. Preliminary report on the geology of the LaHave River area, Nova Scotia. Current Research, Part A.
Geological Survey of Canada, Paper 85-1A, pp. 789-794.

PATTISON, D. . and HARTE, B. 1985. A petrogenetic grid for pelites in the Ballachulish and other Scottish thermal aureoles. Journal of the Geological Society of London, 142. pp. 7-28.

PIGAGE, L.C. , and GREENWOOD, H.J. 1982. Internally consistent estimates of pressure and temperature: the staurolite problem. American Journal of Science, 282, pp. 943-969.

RAESIDE, R.P. WHITE, C.E. and WENTZELL, B.D. 1985 Metamorphic development of southern Nova Scot1a. Geological and Mineralogical Associations of Canada. Program w1th Abstracts. 10, p. A50

ST. ONGE, M.R. 1984. Geothermometry and geobarometry in pelitic rocks of north-central Wopmay Orogen. Northwest Territories, Canada. Geological Society of America Bulletin. 95. pp. 196-208.

THOMPSON, A.B. 1976. Mineral reactions in pelit1c rocks: II. Calculations of some $\mathrm{P}-\mathrm{T}-\mathrm{X}(\mathrm{Fe}-\mathrm{Mg})$ phase relations. American Journal of Sclence, 276, pp. 425-454.

TRACY, R.J. 1982. Compositional zoning and inclusions in metamorphic minerals. In Characterization of Metamorphism through Mineral Equilibria. Edited by J.M. Ferry. Reviews in Mineralogy, 10. Mineralogical Society of Amer1ca, pp. 355-397.

WALDRON, J.W.F. and GRAVES, M. 1987. Preliminary report on sedimentology of sandstones, slates, and bloclast1c carbonate material in the Meguma Group, Mahone Bay, Nova Scotia. Current Research, Part A, Geological Survey of Canada, Paper 87-1A, pp. 409-414. 